\title{
THE DIAMOND DEPOSITS OF KALIMANTAN, BORNEO
}

\author{
By L. K. Spencer, S. David Dikinis, Peter C. Keller, and Robert E. Kane
}

The island of Borneo is one of the oldest known-and least reported on-sources of diamonds. Although diamond mining historically was concentrated in the western area of what is now Kalimantan, recent activity has focused on the alluvial deposits in the southeast. A progress report on the first bulk sample pit in this area found that significant amounts of diamonds appear to be concentrated beneath the center of the Danau Seran swamp. The traditional hand-mining methods contrast greatly with the sophisticated techniques used to mine the first bulk sample pit. Virtually all of the diamonds recovered are gem quality, although most are relatively small, averaging about 0.30 ct. Future potential for southeastern Kalimantan appears excellent.

\section{ABOUT THE AUTHORS}

Mr. Spencer is a consulting geologist based in inverell, New South Wales, Australia; Mr. Dikinis is a gemologist and independent importer of diamonds and colored stones based in Sonoma, CA; Dr. Keller, a geologist and gemologist, is associate director of the Los Angeles Counly Museum of Natural History, Los Angeles, CA; and Mr. Kane is senior siafl gemologist at the GIA Gem Trade Laboratory, Inc., Santa Monica, CA.

Acknowledgments: L. Spencer would like to thank W. W. Shaw, Charles Watson, Acorn Securities, P. T. Aneka Tambang, and Keymead Ply., Lld., for their cooperation. S. D. Dikinis wishes to thank Tom Aligelt, and Chris Johnston for sponsoring his trip; Daum and Vyga Dikinis, Janet Montgomery, Albert Johnsion, Cheryl Kremkow, Rosaline Chow, Colin Curtis, Michael Horovitz, and Fillip Freeman for their support; and Mrs. Helly and Mr. and Mrs. Kuntadi for their guidance. (C) 1988 Gemological Institute of America
B orneo is an island of the Indonesian Archipelago located in the western Pacific Ocean. It is divided into the Malaysian states of Sarawak and Sabah and the Britishprotected, oil-rich sultanate of Brunei to the north, and the Indonesian state of Kalimantan to the south. The coastal areas of Kalimantan are relatively accessible and well known. However, the interior, which comprises approximately two-thirds of the island, is still very remote, and little has been published on its potentially vast mineral resources. Yet, along with India, Kalimantan has historically been one of the world's oldest sources of fine diamonds (figure 1). Renewed interest in the diamonds of the area has prompted a great deal of geologic investigation. The purpose of this article is to review what little is known of these remote deposits and to report on recent geologic exploration of, and development activity in, the Banjarmasin-Martapura area of southeastern Kalimantan (the province of Kalimantan Selatan). The gemological characteristics of diamonds recovered from this area will also be discussed.

In December 1985, Acorn Securities lan Australian public company) together with Keymead Pty. Ltd. (a British private concern) executed a joint exploration and production agreement with the firm P. T. Aneka Tambang/representing the Indonesian government) to explore for diamonds in the Banjarmasin-Martapura area of southeastern Kalimantan (figure 2). The areas subject to the agreement have had a long history of gem-quality diamond production.

During the 1970s, P. T. Aneka Tambang conducted extensive exploration on the fanglomerate gravels (i.e., those materials that were originally deposited as an alluvial fan) of the Riam Kanan River, with generally negative results. Little exploration was conducted beneath the extensive swamps in the area, however, even though local residents have recovered diamonds for several hun- 


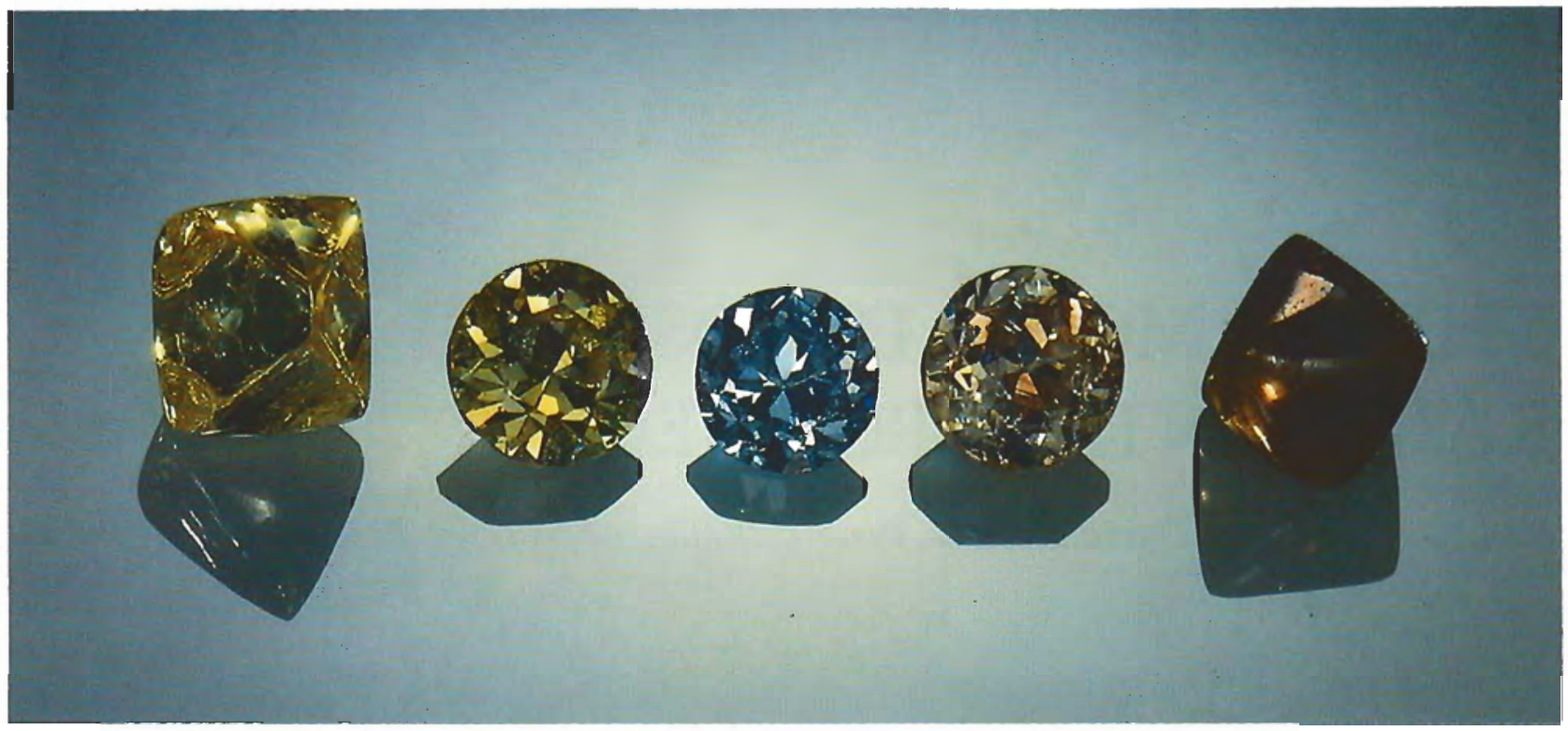

Figure 1. Two recently found crystals $(0.76$ and $0.68 \mathrm{ct}$, respectively) flank three older faceted examples of fancy-color diamonds found in Borneo. The three faceted diamonds, $0.20-0.34 \mathrm{ct}$, were recovered from the Cempaka diamond fields early in this century and subsequently faceted in Martapura. Photo (c) Harold es) Erica Van Pelt.

dred years on the flanks and margins of the swamps by sinking shafts to the gravel horizon. Deep water and extensive overburden precluded extending the workings to the center of these swamps. Exploration and development work by Acorn in this area has shown that these swamps do indeed contain significant diamond deposits. The information presented here is based largely on a geologic exploration progress report on the Banjarmasin area that was prepared by the senior author (L. K. Spencer) in October 1987, on the visit of S. D. Dikinis to Banjarmasin and other areas of Kalimantan in the summer of 1987, and on geologic research and gemological testing performed by P. C. Keller and R. E. Kane.

\section{HISTORY}

The diamond deposits of Borneo are believed to share with India the distinction of being the earliest worked diamond mines in the world /see box), although researchers have not been able to pinpoint the exact date that mining began. For example, Webster (1983) believes that mining may have started on the island as early as 600 A.D., and that mining was certainly carried out since the 14th century. Bruton (1978) does not believe that mining in Borneo started until the 16th century. Schubnel (1980), however, provides strong evidence that the area on the Sungai Landak (Landak River) in western Kalimantan was worked by the Malays and Chinese as early as the Sung period
(960-1279 A.D.). Numerous fragments of Chinese pottery traced to this period have been found in the diamond workings. In the 16 th century, the Portuguese reached Borneo and noted the workings on the Landak River. Cutting, probably learned from India, was done in shops in Ngabang and Pontianak. In the early 17th century, the Dutch colonized Borneo and began exploiting the diamonds through the Dutch East India Company. Tavernier (1676) reported that in the 17 th century, Borneo paid annual tributes to the Chinese emperor and that part of each tribute was in diamonds.

For the most part, early production records appear to be unreliable. Although several thousand workers were reported in Tanah Laut, near Martapura, in 1836, the Dutch government listed a total diamond production of only 29,857 ct between 1836 and 1843 (Bauer, 1904). These figures do not differ significantly, however, from the $25,378 \mathrm{ct}$ estimated by merchants at Ngabang for production between 1876 and 1880 . Bauer reported that "in 1880 the mines on the Sekayam River were worked by about 40 Chinese only, those in Landak gave employment to about 350 workers." With the discovery of diamonds in South Africa in the late 19th century, Borneo's diamond production became insignificant. Whereas an estimated $6,673 \mathrm{ct}$ of diamonds were produced in western Kaliman$\tan$ in 1879 , that number dropped steadily to only $600 \mathrm{ct}$ in 1907 and minor amounts subsequently. 
During the period 1913-1936, diamond production in southeastern Kalimantan fluctuated between 236 and 2,152 ct, but started a significant upward rise from $907 \mathrm{ct}$ in 1937 to 3,292 ct in 1939 /Van

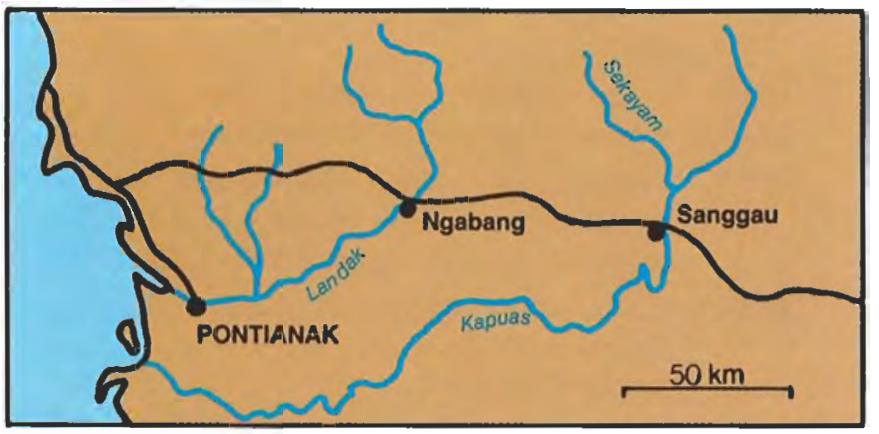

Bemmelen, 1939). Today, production in western Kalimantan is minimal, and mining activity and exploration are concentrated in the southeast, near Banjarmasin and Martapura.

Figure 2. This map shows the two major areas lleft $=$ the Landak district of western Kalimantan, below = the Banjarmasin-Martapura area of southeastern Kalimantan) where diamonds have been found in the Indonesian state of Kalimartan, on the island of Borneo. Artwork by Jan Newell

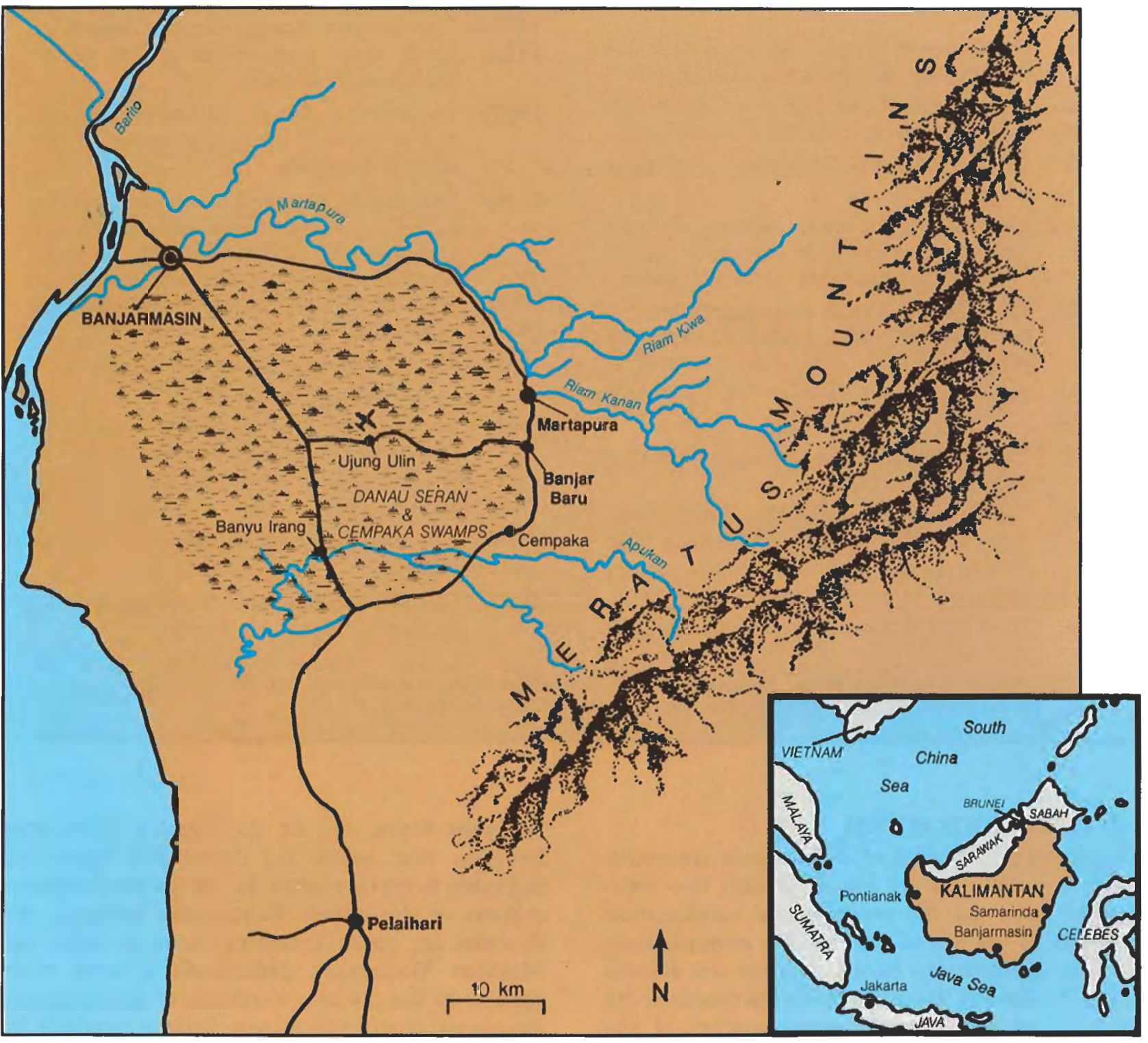




\section{A Brief History of Diamond Mining in Kalimantan.a}

600 Hindus are probably the first to discover diamonds (Webster, 1983).

700- The Malays vanquish the Hindus and initi1000 ate the first diamond mining.

960- Chinese miners work the Landak area for 1279 gold and diamonds (Schubnel, 1980).

1518 Duarte Barbosa, of Portugal, provides the first written reference to diamond mining in Borneo.

1540 Feran Mindez Pinto, of Portugal, provides the first description of diamond mining.

1565 Garcias ab Horto, of Portugal (Goa), provides the first description of the quality, shape, and other characteristics of Borneo diamonds.

1598 De Moraga, of Spain (Philippines), mentions the first Portuguese trading in diamonds.

1604- Captains Middleton and Sare are the first 1609 Englishmen to describe the diamond mines.

1608 The first Dutch trading posts are set up at Pontianak.

1631- Jean Baptiste Tavernier provides the first

1689 detailed description of diamonds and of flourishing trade at Batavia (now Jakarta).

1650s The Dutch East India Company exercises a full monopoly on diamond trading from Borneo.

Late The Martapura diamond field is discovered. 1600s

1698 The first British trading post in Borneo is set up at Banjarmasin.

1738 The Dutch East India Company exports 300,000 guilders worth of diamonds from the Landak district in what is now western Kalimantan.

1789 The 367-ct Matan diamond (which may have been quartz) is reportedly found in the area of the Landak River.

1780- The Dutch East India Company experiences

1800 a decline in its trade monopoly and diamond mining.

1810 - Stamford Raffles, governor of Java, writes an 1830 extensive history of the diamond fields.

1823 Englishman George Windsor Earl reports the Dutch purchase of the Sukadana diamond fields for the equivalent of US $\$ 50,000$.

1828 Earl reports the blockading of Pontianak by Dutch gunboats to stop diamond smuggling by the Chinese.

1842 Chinese miners are massacred at Landak.

1880s - The discovery of major diamond deposits in

1920 s South Africa leads to the decline of the Borneo diamond fields.

1930s The Dutch undertake mining at Cempaka and attempt to trace the source of the alluvial diamonds.

1940s Production (unrecorded) continues after the Japanese invasion. Many Japanese vessels carry gems during the occupation. The cargo carried by the cruiser Ashigara when it was sunk off the coast of Sumatra is valued at $£ 4,000,000$.

1949 The Netherlands transfers sovereignty to an independent Indonesia.

1965 166.85-ct Tri Sakti diamond is found in Kalimantan and subsequently faceted to produce a 50.53-ct emerald cut ("Petrified Tears," 1977).

1970 s. T. Aneka Tambang initiates exploration at Cempaka.

1985 The Aneka Tambang-Acorn SecuritiesKeymead joint venture is signed.

aUnless otherwise indicated, the information in this table was derived primarily from Ball (1931) and discussions with local residents and officials at the Banjar Baru Museum.

\section{LOCATION AND ACCESS}

The diamond deposits of Kalimantan are exclusively alluvial and are clustered into two welldefined areas on the western and southeastern portions of the island. In extreme western Kalimantan (Kalimantan Barat), deposits are known along the Landak River near Serimbu (north of the city of Ngabang), on the upper reaches of the
Sekayam River, and on the Kapuas River near Sanggau just below its confluence with the Sekayam River (see figure 2). On the southeastern portion of the island (Kalimantan Selatan), the deposits are concentrated in rivers draining the Meratus Mountains, principally around Martapura, $39 \mathrm{~km}$ (24 mi.) southeast of Banjarmasin, the capital city of Kalimantan Selatan province. In 
this area, workings are found near Cempaka (the $c$ is pronounced as $c h$, on the Apukan River, and also along the Riam Kanan and Riam Kiwa Rivers.

The Acorn Securities exploration project, the most extensive currently being undertaken, has concentrated activities in the districts of Cempaka, Banyu Irang, and Ujung Ulin lagain, see figure 2). The project area is centered around longitude $114^{\circ} 45^{\prime}$ east and latitude $3^{\circ} 30^{\prime}$ south. The project can be reached from Jakarta by jet to Syamsuddin Noor airport, which is located adjacent to, and immediately north of, the concession boundary. A paved road is also available from Banjarmasin to Banjar Baru, where the company's camp is located, a distance of about $45 \mathrm{~km}(28 \mathrm{mi}$.). As in all parts of Kalimantan, access to areas away from the main road is difficult, especially during the rainy season, which lasts from October through March in southeastern Kalimantan.

The Meratus Mountains, which form the dominant geographic feature adjacent to the project area, are characterized by rugged topography and narrow, sharp ridges with well-developed V-shaped valleys. "Two major rivers - the Riam Kanan and the Riam Kiwa-drain the Meratus Mountains.

Flanking the Meratus Range is a series of low, undulating hills. These grade into grass-covered swamps, at or slightly below sea level, which dominate the Banjar Baru area. The water level in the swamps ranges from 1 to $3 \mathrm{~m}$ during the rainy season, but during the peak of the dry season (August to September) it is possible to walk over some of the upstream areas. Elevated laterized sediments (i.e., red, iron- and aluminum-rich products of rock decay) flank the northern and southern boundaries of the swamp area, with a tongue of slightly elevated ground dividing the swamp in the center of the study area. This tongue defines the Danau Seran swamp to the northeast and the Cempaka swamp to the south. The major drainage within the project area is the Apukan River, which defines the course of the Cempaka swamp along its southern margin. No active watercourse exists in Danau Seran, but several small drainages disgorge their flow directly into the swamp. Parts of both swamps-although more commonly the Cempaka-are irregularly cultivated for rice.

Inasmuch as the region is close to the equator, the climate is characterized by high temperatures (up to $35^{\circ} \mathrm{C}-95^{\circ} \mathrm{F}$-from July to October) and humidity. The driest months are May to October; December and January have the greatest rainfall.
The island of Borneo has an average rainfall of approximately $500 \mathrm{~cm}$ (200 in.) per year.

\section{GEOLOGY OF THE KALIMANTAN DIAMOND DEPOSITS}

Previous Work. The Indonesian Geological Survey published the most comprehensive compilation of available geologic mapping for Kalimantan (Hamilton, 1970). This report presents the general geology and tectonic history of this area, although it does not discuss the diamond occurrences. The earliest geologic report on diamonds in Borneo was written by R. D. M. Verbeck, an early director of the Geological Survey of the Dutch East Indies. His report, which appeared in Boutan (I886), remains one of the few published descriptions of the geologic occurrence of Borneo's diamond deposits.

Diamond Occurrences. From the 1930s into the 1980s, the "Pamali Breccia" was believed to be a possible primary source of at least some of the diamonds in Kalimantan. However, recent work has shown that this breccia may be a sedimentary rock with no primary kimberlitic affinities. To date, no kimberlites or related lamproites have been located in Kalimantan. Nixon and Bergman (1987) suggest that the primary source of the Kalimantan diamonds are ophiolites - a suite of mafic and ultramafic rocks which are believed to represent mantle material that has been thrust up onto the earth's surface when continental plates collide. Kalimantan underwent significant plate collision during Cretaceous time, and ophiolites have been found in Kalimantan. It is important to note that this theory is untested, and while the mantle peridotites may contain diamonds, it is questionable that diamonds could survive the relatively slow $150-\mathrm{km}$ trip to the earth's surface without converting to graphite. Diamond-bearing alluvial deposits at Cempaka, downstream from the Meratus Mountains (which include ophiolites), do not contain any classic diamond indicators or large amounts of bort; only one piece of bort was found among the 6,766 diamonds recovered at Acorn Securities' first bulk sample pit. Percussion fractures, the lack of cleavages, and the relatively clean nature of the material indicate that the diamond source is probably far removed, lesserquality material having been eliminated over the distance traveled.

Within the Meratus Mountains, diamonds have been found in the Upper Cretaceous con- 
glomerates of the basal layers of the Manunggul Formation (one of the main stratigraphic formations in the areal and have been mined from these rocks at the Pinang River, a tributary of the Riam Kiwa. This same formation is believed to be the source of the Cempaka deposits. The continual emergence of the Meratus Mountains has ensured a constant supply of diamondiferous material to the major drainages of the Riam Kanan and Riam Kiwa. Several periods of uplift, erosion, and resedimentation are evident in the late Tertiary and Quaternary sediments flanking the Meratus. Such multiple erosion and sedimentation cycles are considered important in the formation of economic placer deposits.

The exploration concept applied by Acorn geologists at the Banjar Baru project is that weathering of the late Tertiary laterized gravels by tectonic uplift would result in their erosion and deposition into surrounding swamps. Deposition of reworked gravels would occur as paleochannels (ancient riverbeds) and lag deposits on previously scoured basement irregularities. It was suspected that reworking would result in higher in-situ diamond grades within the paleochannels beneath the swamps than in the laterized sediments. It was Acorn's task to identify the location of these ancient riverbeds and to bulk sample them with a view to probable exploitation.

Acorn's work at the Danau Seran test pit readily proved this hypothesis of an ancient riverbed beneath the swamp. Geologists have identified three main sediment facies (stratigraphic bodies): paludal (swamp), sheet wash, and alluvial (figure 3). Diamonds are found principally in the alluvial facies. The (upper and lower) paludal sediments generally constitute the bulk of overburden that covers the diamond-bearing channel gravels. The thickness of this overburden varies from less than $2 \mathrm{~m}$ near the headwaters of Danau Seran to $10 \mathrm{~m}$ downstream. The sheet-wash facies consist of sediments that have been derived from erosion and subsequent resedimentation of laterite gravels and sediments. They usually occur around the margins of the swamps, but have also been found beneath paludal sediments and on the flanks of eroded valleys away from the swamp altogether. These sediments are usually red to brownish red

Figure 3. This diagram shows the schematic relationship of the main sediment types (the trigons indicate the diamondiferous layers) at the Danau Seran sample pit in southeastern Kalimantan. Note that the relative thicknesses of the various types and the swamp level are not exact. Artwork by Jan Newell.

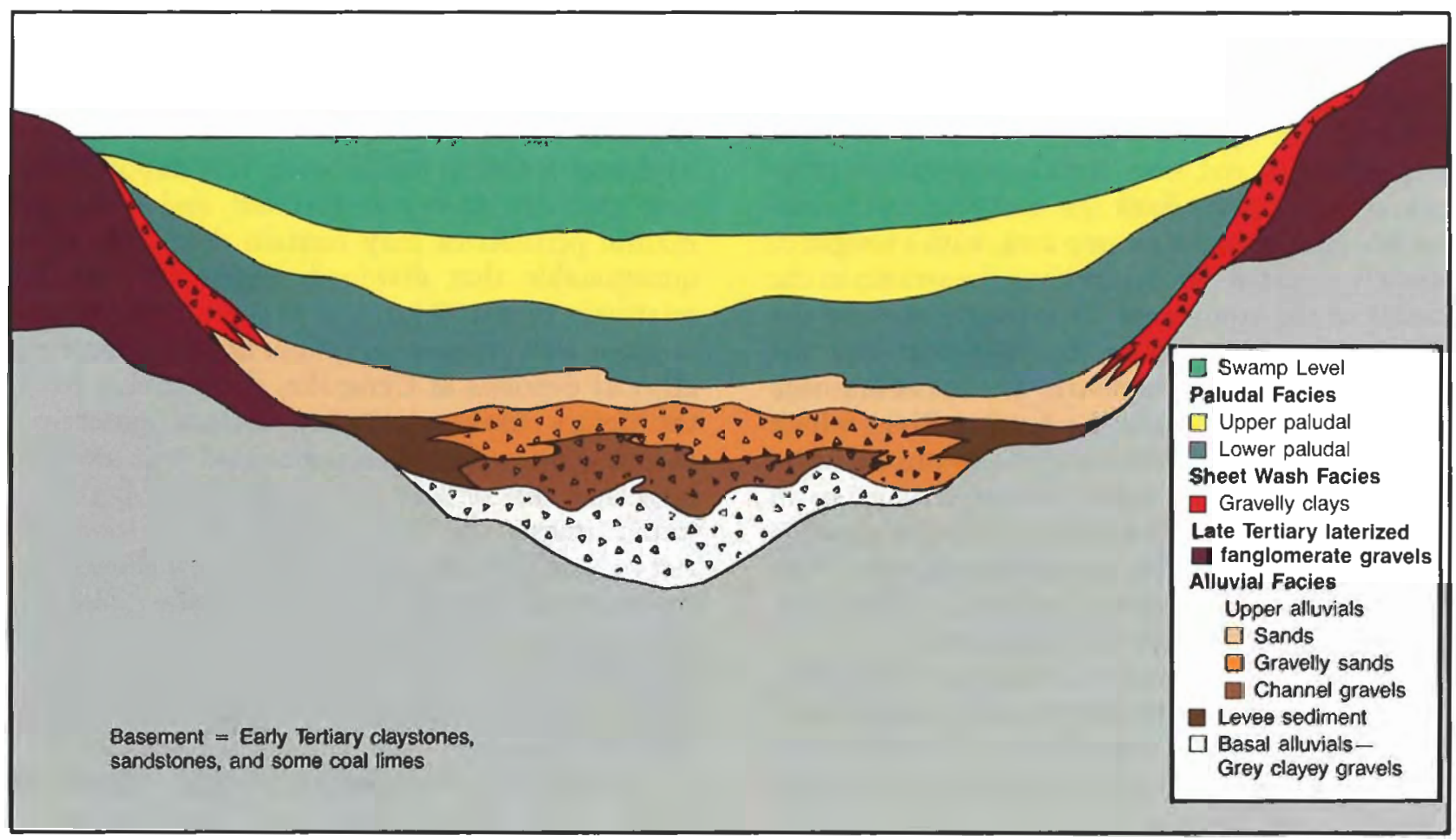




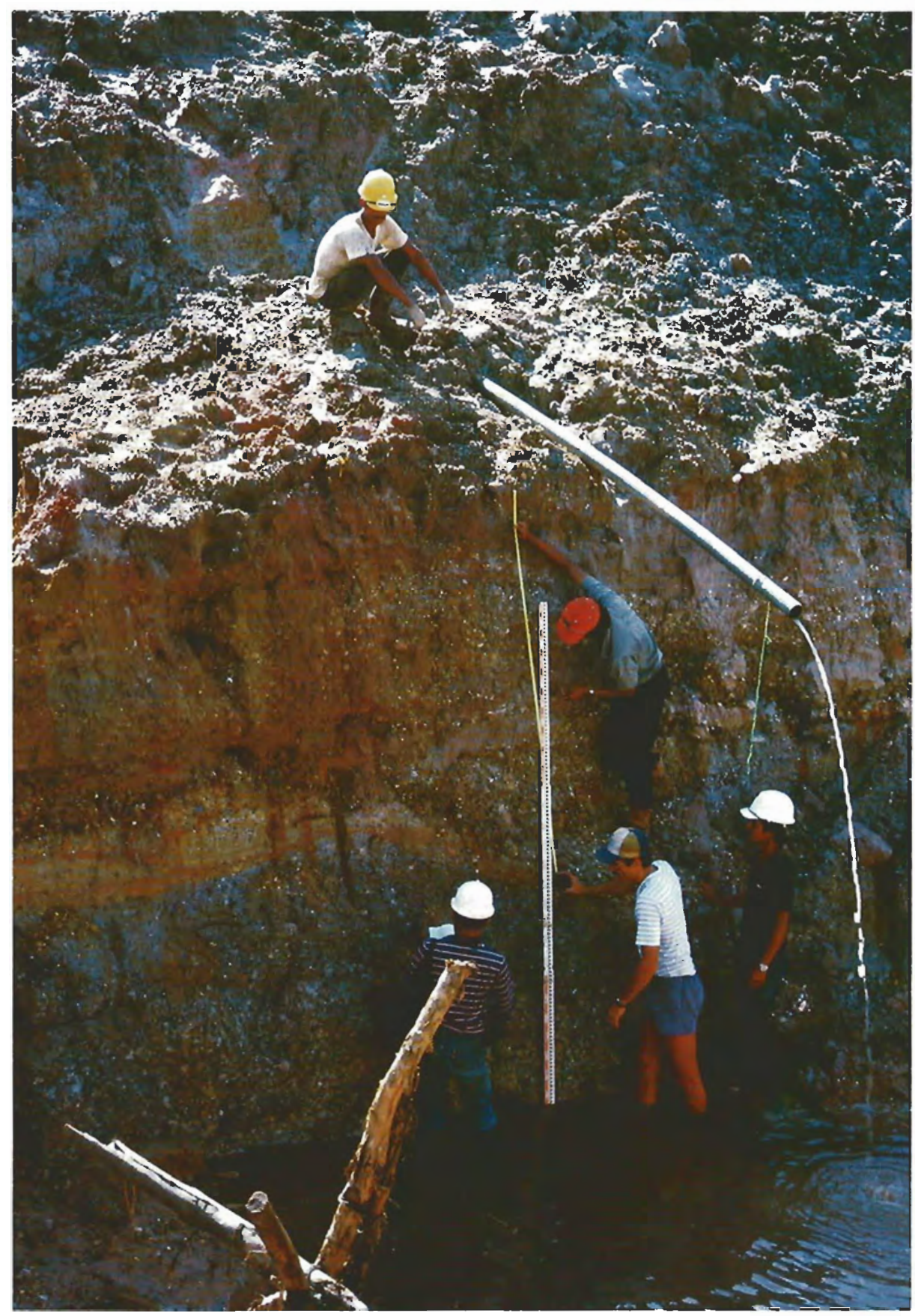

Figure 4. In this view of the wall of one of the sample pits dug by Acorn Securities at the Danau Seran swamp, the upper alluvial gravels (the yellowish brown sediments that are the principal source of diamonds) can be seen lying above the basal alluvial layer. Gravel thicknesses were measured at 1-m intervals all around the inside walls of the pit. Photo courtesy of Acorn Securities.

but may be mottled white; characteristically, they contain abundant iron oxide nodules. Sheet-wash sediments are invariably clay rich and may contain diamonds in addition to other heavy minerals. A large percentage of native workings on the periphery of the swamp involve these sediments. The third main facies, the alluvial diamond-bearing gravels, are derived from river action and sedimentation. The alluvial gravels have three main subdivisions: the upper alluvial (peripheral and channel), the levee, and the basal alluvial sediments.
The bulk of the diamondiferous sediments occur in the upper alluvials, which are characterized by coarse gravels, sandy gravels, gravelly sands, and coarse gritty sands; these upper gravels are often yellowish brown to white or grayish white (figure 4). The diamonds are usually associated with gravel lithologies of quartz, schist, intrusives, and fragments of volcanics of broad composition. Corundum, rutile, and gold are considered good indicators for diamonds.

In summary, the Acorn Securities project has 


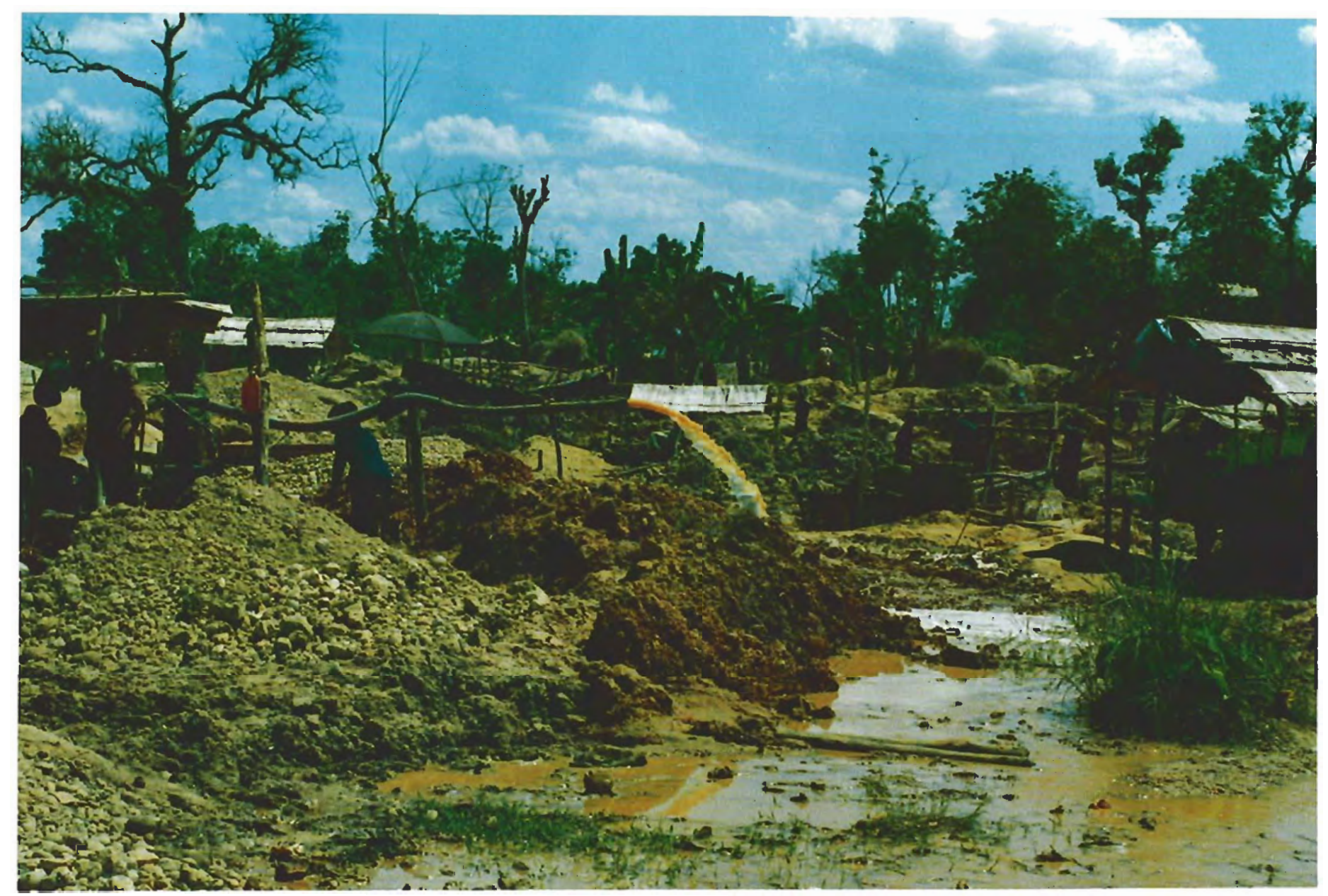

Figure 5. The Cempaka mining area is a jumble of shafts and tailings. When a pit is exhausted, the miners move a small distance to continue extracting the gem-bearing gravels. Because the upper gem gravels have been largely worked out, mining is more difficult and the miners are more likely to work as a team. Photo by David Dikinis.

suggested that the principal source of the diamonds found in southeastern Kalimantan is associated with erosion of the late Cretaceous Manunggul Formation. These diamonds were subsequently deposited and re-eroded several times before being finally deposited in later Tertiary and Quaternary sediments. Two of the three main sedimentary facies identified at Banjar Baru are known to contain diamonds: the sheet wash and the upper sections of the alluvial gravels. The majority of diamonds occur in the upper alluvial materials, the distribution of which corresponds to the outline of paleochannels emanating from the Danau Seran and Cempaka swamps, and represents the reworking of previously eroded diamondiferous sediments.

In the western area of Kalimantan, around Ngabang, diamonds also occur in ancient stream channels of probable Eocene age, and in recent stream beds that drain exposed areas of these ancient stream channels, usually near the flanks of mountains (see Bauer, 1904). The Eocene gravels exhibit no bedding, and diamonds appear to be evenly distributed. The gravels consist of moder- ately to well-rounded metamorphic and igneous rock fragments and quartz pebbles. As in southeastern Kalimantan, fragments of corundum are found in the gravels and are used by the miners as a good indicator of diamonds. The corundum, which is not gem quality, is commonly accompanied by magnetite, muscovite, and economically important amounts of gold and platinum. The gravels of the Eocene-age stream channels typically occur only sporadically throughout the region and are always well above sea level (Bauer, 1904).

\section{MINING METHODS}

Traditional Mining. Near the town of Cempaka are found traditional mining sites. The mines have been slowly moved as old workings have been depleted. In recent years, however, many of the local miners have left the area for the alluvial gold fields west of Samarinda in the eastern and central parts of Kalimantan. In July 1987, fewer than 500 miners were actively using traditional methods in Cempaka. Because the upper gem-bearing gravels have largely been worked out, mining is more difficult now than in the past. The gem-bearing 
gravels are as much as $10 \mathrm{~m}$ below the surface of the swamp, with the water table lying just underground. The miners now usually work together in a communal mining association (figure 5). It is interesting to note that women are involved in every element of the work except the strenuous lifting of equipment.

Toiling under the hot equatorial sun, the miners first start digging a shaft at the chosen site. They soon bring in lumber for supports and also construct a lean-to to shield the workers from the sun. A four-cylinder car engine is connected to a 10-cm-diameter pump to remove the constant inflow of water (figure 6). The sides of the shaft are well supported, and swamp grass is woven together and shoved between the timbers to staunch the constant oozing of the swamp. The miners work

Figure 6. A car engine is commonly used to pump water from the mine shafts at Cempaka. Photo by David Dikinis.

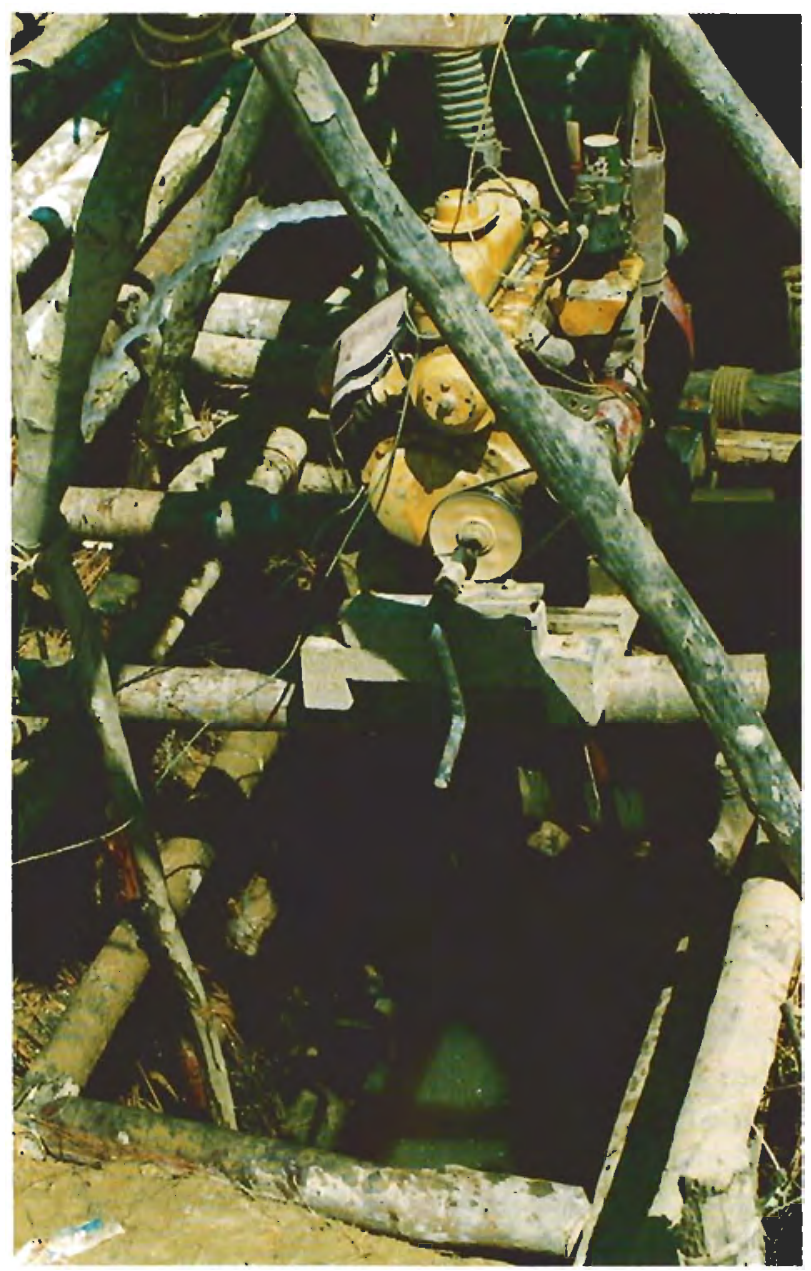

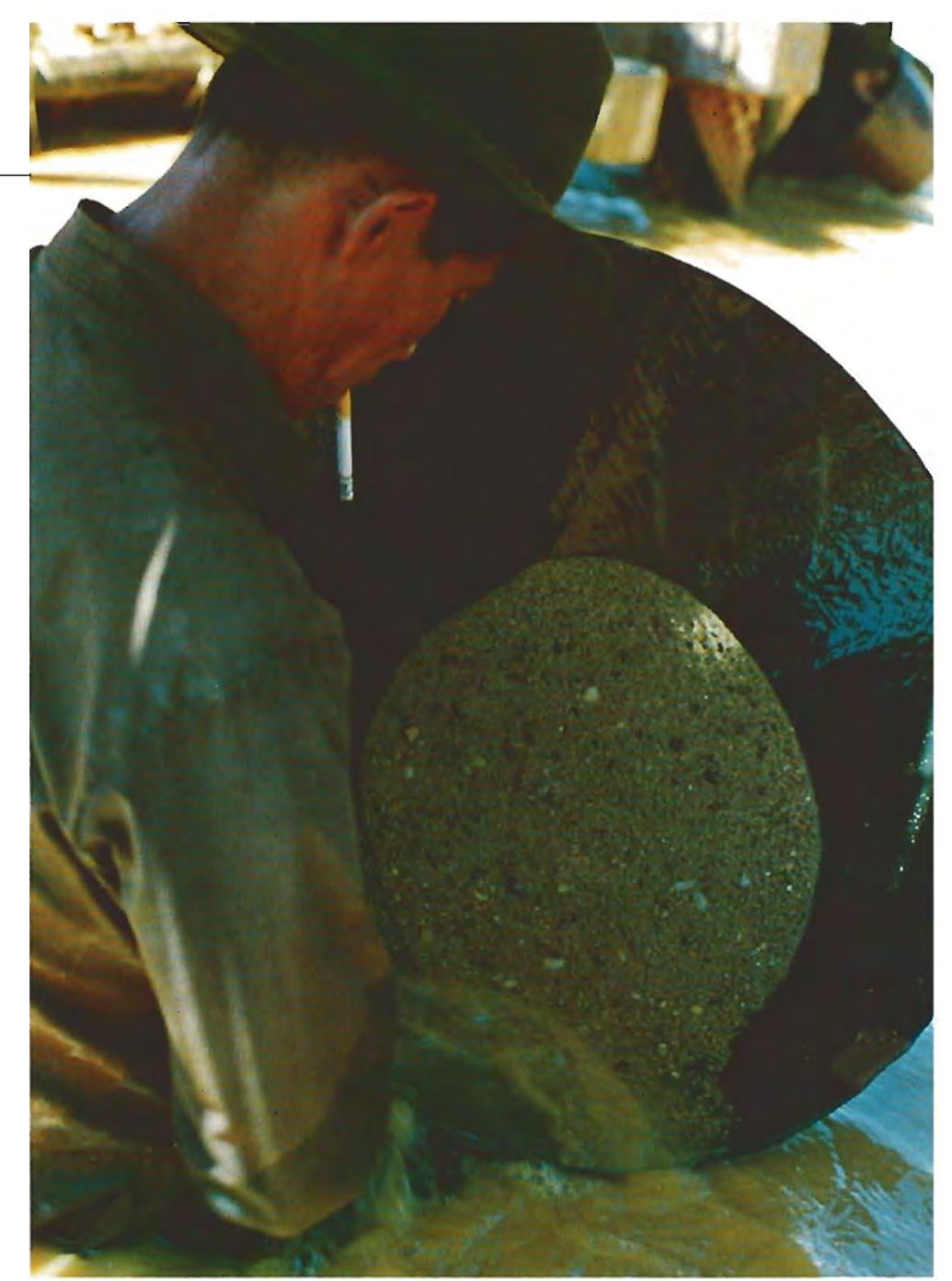

Figure 7. The black ironwood dulang (pan) and clove cigarette are trademarks of the diamond panner at Cempaka. Photo by David Dikinis.

from near sunup to sunset every day except Friday, which is the Moslem holy day. They break for coffee and lunch at one of the many "snack bars" that are set up in the gem fields by enterprising "members of the family."

The camp is in continual activity, with pumps running, miners (including the women) digging, and young boys hauling baskets of gem-bearing gravel to the stream bank, where yet another team of workers washes it. The washers clean and concentrate the gravel in long hollowed-out logs set into the stream. The gravel is poured into one end of the log and then worked by the washers first with their feet to clean off silt and later by hand to remove the lighter gravel and larger rocks. The concentrate is then divided among the panners, who squat waist deep in the stream with a dulang (pan) made of black ironwood which they swish relentlessly in search of that large white diamond that will make them all rich (figure 7). When a stone is found, it is presented to the group's leader, 


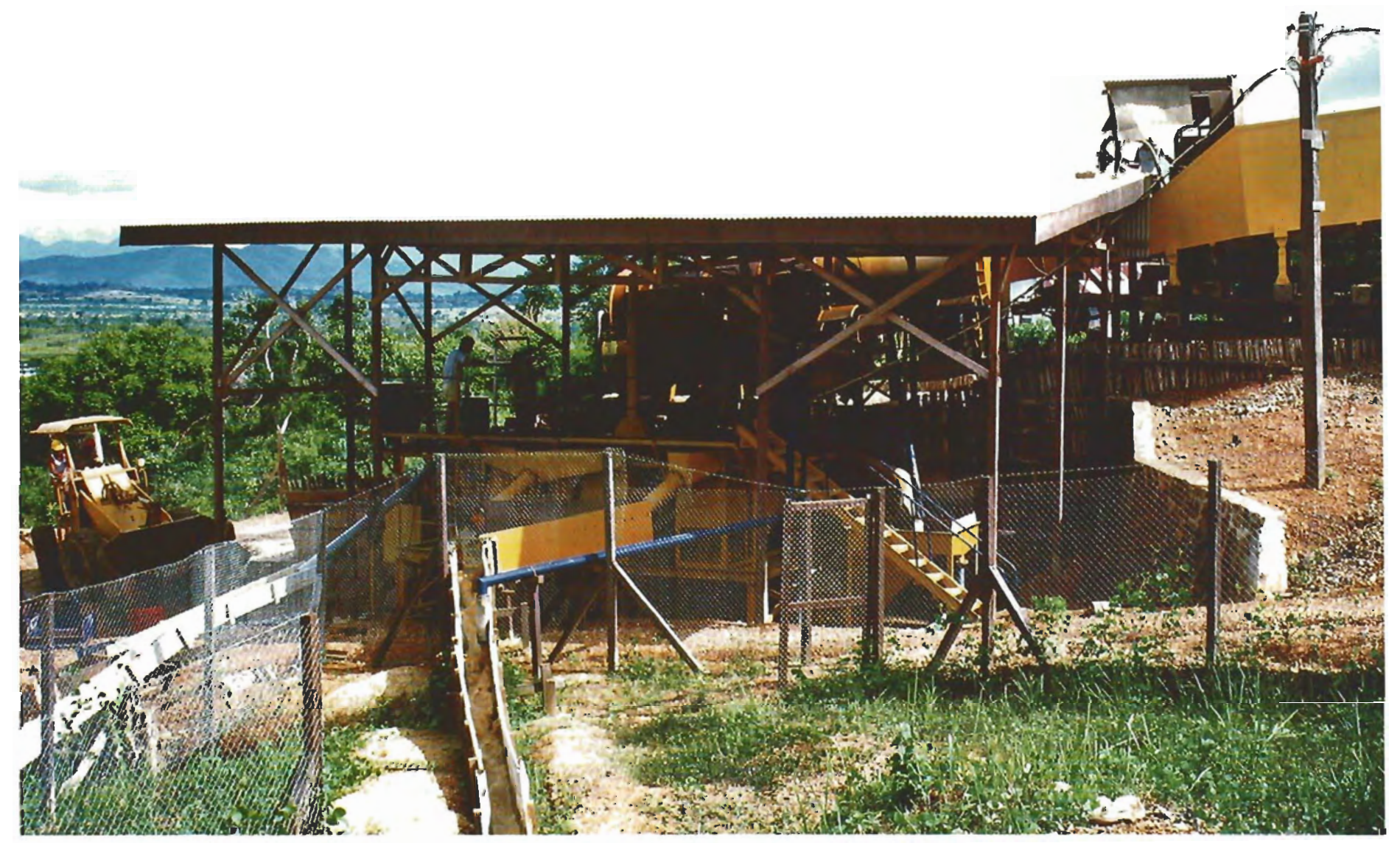

Figure 9. This sampling plant, located $5 \mathrm{~km}$ from the Danau Seran sample pit, is basically the same as that used to separate sapphire at Inverell, Australia. Photo courtesy of Acorn Securities.

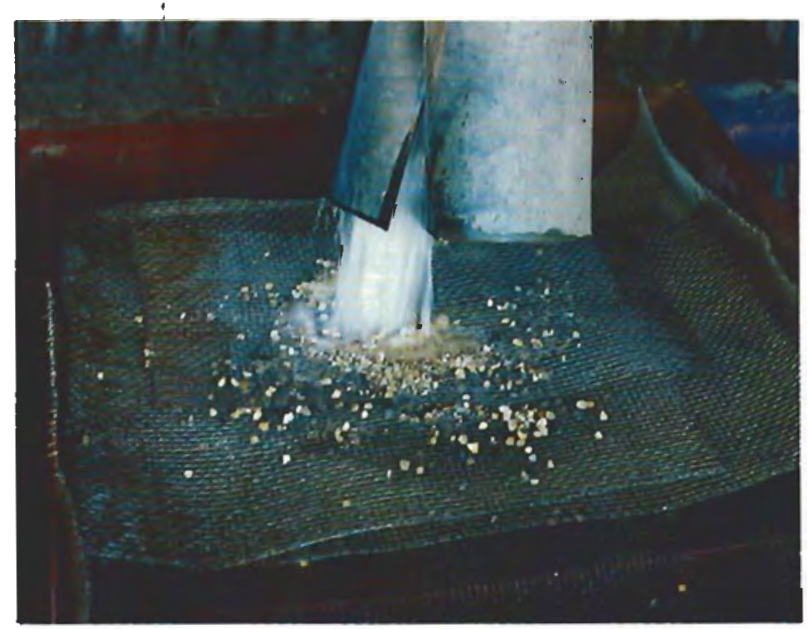

Figure 10. Material emitted from the jigs at the Acorn Securities sampling plant will be further examined by hand for diamond rough. Photo by David Dikinis.

\section{DESCRIPTION OF THE \\ KALIMANTAN DIAMONDS}

Quality Analysis of Diamonds from Banjarmasin. Acorn Securities reports that the great bulk of the diamonds they recovered are of gem quality, with only one piece of bort recovered from 6,766 individual stones found in the bulk sample pit. The

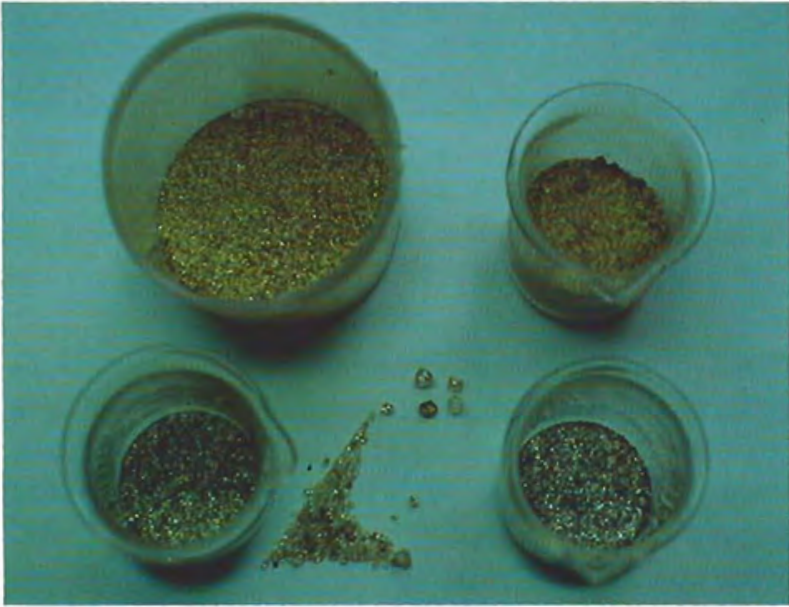

Figure 11. In addition to over $1,000 \mathrm{ct}$ of diamonds (some of which are shown here in the center), 470 grams of gold and 178 grams of platinum were recovered from the first bulk-sample pit at Danau Seran. Photo by David Dikinis.

diamonds occur as stones and shapes with uncommon cleavages, as well as some macles and, rarely, ballas (figure 12). The dominant crystal forms of the stones and shapes are the dodecahedron and tetrahexahedron $158 \%$; C. E. Watson, pers. comm., 


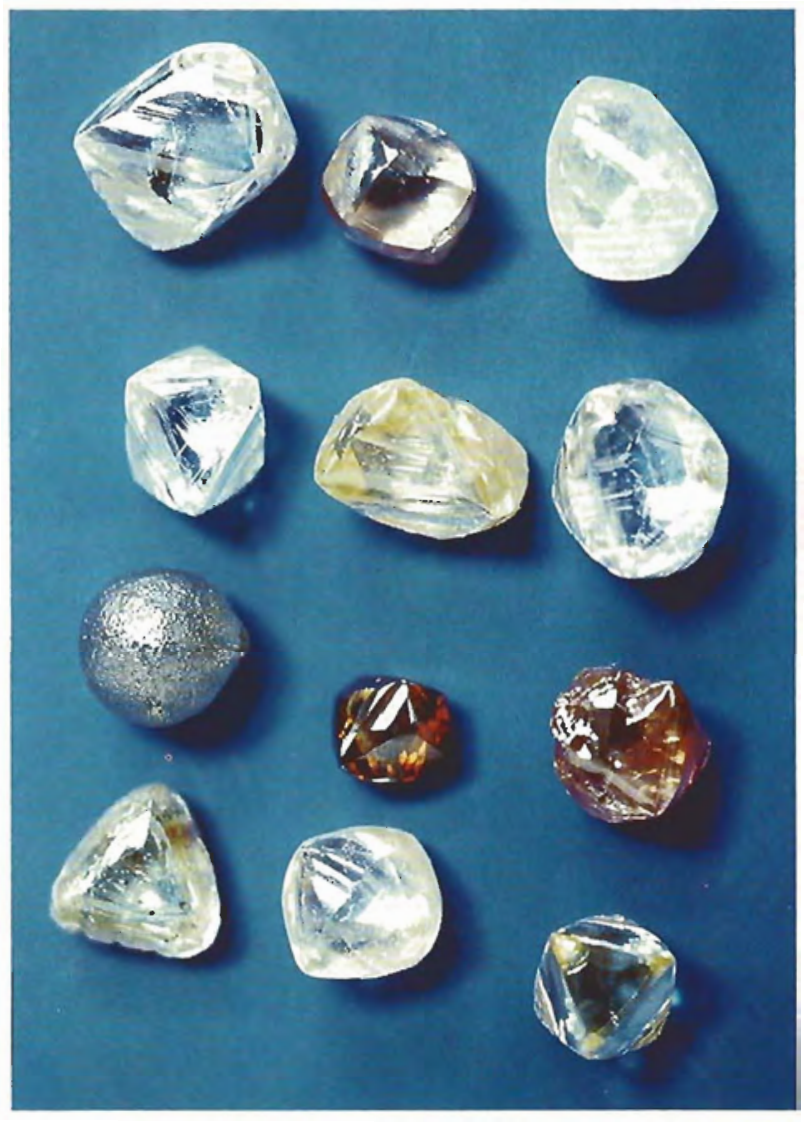

Figure 12. A variety of colors and shapes of diamonds (here, $1-3 \mathrm{ct}$ ) were found in the first bulk sample recovered from Danau Seran. Photo courtesy of Acorn Securities.

1988) followed by the octahedron (22\%). The goods generally show low amounts of inclusions. White $(46 \%)$ and yellow $(33 \%)$ stones are the dominant color groupings, although brown $15 \%$, including cognac and champagne colors), green $(5 \%)$, and other colors $(1 \%)$ were also recovered. Of the larger stones cut, that is, stones greater than $2 \mathrm{ct}$, the highest color rating was a J. Because of the shapes in which the diamonds occur and their overall quality, independent valuers in both London and Antwerp have deemed the material eminently "sawable."

The largest stone recovered from this area in recent months is a 33-ct octahedron found by a local miner. The largest stone recovered during the Acorn sampling was an 8.53-ct octahedron (figure 13 that cut a 3.50-ct stone of J color. Twenty percent of the stones by weight are larger than 0.8 ct, with $48 \%$ of the stones larger than $0.30 \mathrm{ct}$. Approximately $15 \%$ of the stones are larger than $1 \mathrm{ct}$.

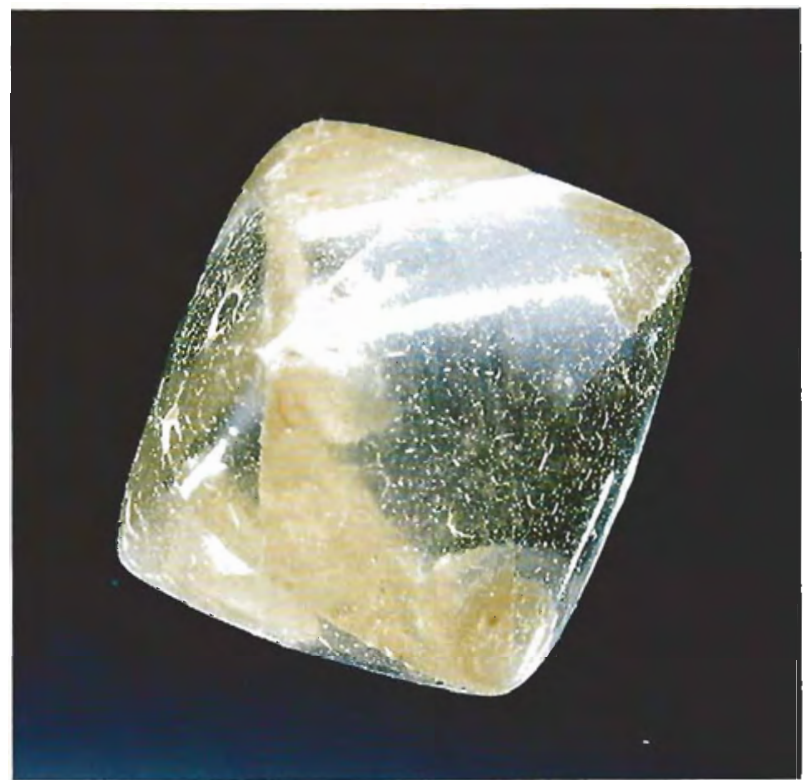

Figure 13. This 8.53-ct diamond from the first bulk sampling pit at Danau Seran cut a 3.5-ct stone of J color. Photo courtesy of Acorn Securities.

Gemological Properties. Comprehensive gemological testing of the three fancy-color faceted stones shown in figure 1 and the near-colorless crystal shown in figure 14 confirmed that the properties of these Kalimantan diamonds are the same as diamonds of similar hues from other localities (see table 1). With regard to internal characteristics, no mineral inclusions were observed in the grayish blue diamond when it was examined with the microscope. However, a cloud of pinpoint inclusions was evident throughout the light pinkish brown stone, and numerous black crystal inclusions (which could not be identified without damaging the stone) were noted under the crown and table of the greenish yellow diamond. Both of these characteristics, however, have been observed in diamonds from other localities. Also observed in the greenish yellow diamond was the strong green graining that is typical of this color type from various sources.

Famous Diamonds. Although diamonds over $5 \mathrm{ct}$ from Kalimantan are rare, this does not preclude the occasional discovery of a significant stone. The Jakarta Museum has many diamonds that weigh $10 \mathrm{ct}$ or more. Bauer (1904) reported that several stones over $100 \mathrm{ct}$ once belonged to the Malay Prince of Landak. Since the Landak district was the major producer of diamonds in Kalimantan into 
the early 20th century, it would have been appropriate for the ruling prince to retain the largest stones. Bauer also reported that the Rajah of Matan had several significant diamonds, including a $70 \mathrm{ct}$ named the Segima and an unnamed 54-ct stone. The Rajah of Matan was reported also to have a 367-ct diamond, but it is generally thought that the stone was actually quartz.

In 1965, a diamond weighing 166.85 ct was found in southeastern Kalimantan and named the Tri Sakti, or "Three Principles," after the three watchwords of the new Indonesian republicnationalism, religion, and unity ("Petrified Tears," 1977; Schubnel, 1980). The rough was sent to Asscher's Diamond Company, Ltd., an Amsterdam firm that is renowned for having cut the Cullinan, and a 50.53-ct emerald-cut was produced in 1966. The stone was subsequently sold to an undisclosed buyer in Europe and, unfortunately, its current whereabouts are not known.

\section{THE MARTAPURA DIAMOND INDUSTRY TODAY}

Martapura is the largest diamond-cutting center in Indonesia. In the town square of Martapura, one is immediately aware that this is a gem-trading town. Small jewelry shops are found around the square, and open-front cutting shops predominate in the alleyways. Purchasing diamonds as a tourist

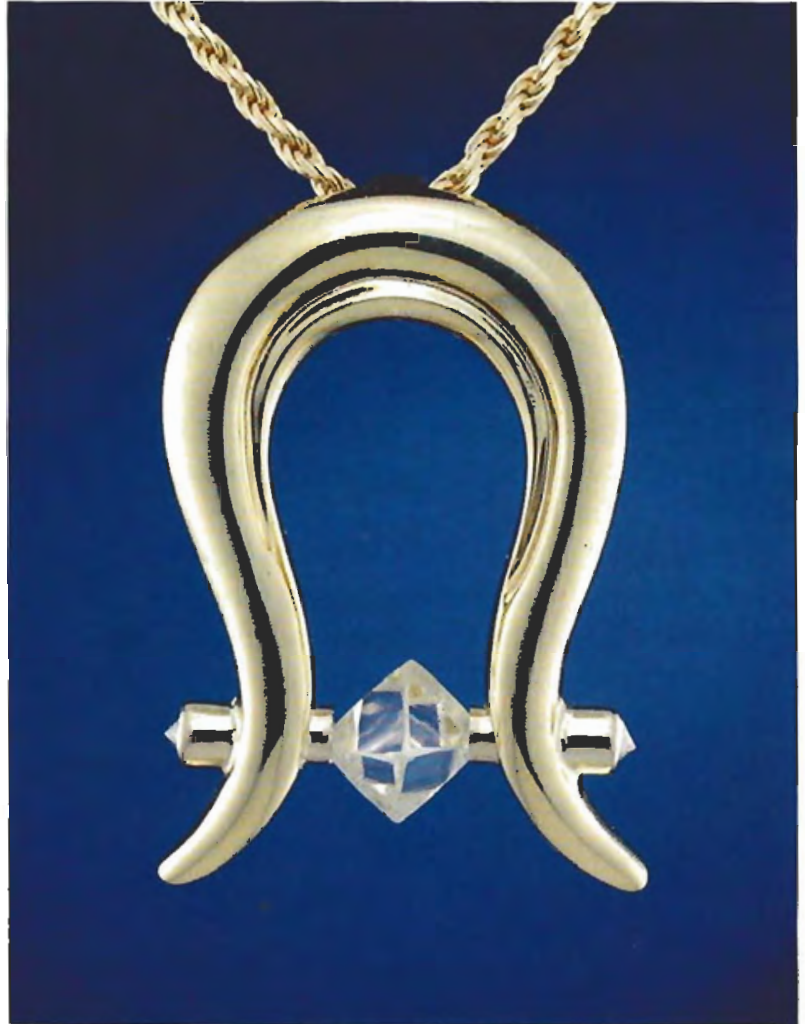

Figure 14. This near-colorless 0.96-ct octahedral diamond crystal from Cempaka is set in an $18 \mathrm{~K}$ gold pendant designed by Diane Allen. Photo (c) Tino Hammid.

\begin{tabular}{|c|c|c|c|c|}
\hline Property & $\begin{array}{l}\text { 0.34-ct fancy light } \\
\text { pinkish brown }\end{array}$ & $\begin{array}{l}0.20 \text {-ct fancy } \\
\text { grayish blue }\end{array}$ & $\begin{array}{l}0.28-c t \text { fancy } \\
\text { greenish yellow }\end{array}$ & $\begin{array}{c}\text { 0.96-ct near- } \\
\text { colorless } \\
\text { octahedral crystal }\end{array}$ \\
\hline $\begin{array}{l}\text { Absorption } \\
\text { spectruma } \\
(400-700 \mathrm{~nm})\end{array}$ & $\begin{array}{l}\text { Strong } \overline{415.5-\mathrm{nm}} \\
\text { line }\end{array}$ & $\begin{array}{l}\text { No lines or } \\
\text { bands }\end{array}$ & $\begin{array}{l}\text { Moderate lines at } \\
498 \text { and } 504 \mathrm{~nm}\end{array}$ & $\begin{array}{l}\text { None at room } \\
\text { temperature; very } \\
\text { weak } 415.5-n m \\
\text { line when stone } \\
\text { cooled to }-54^{\circ} \mathrm{C}\end{array}$ \\
\hline $\begin{array}{l}\text { Transmission } \\
\text { luminescence }\end{array}$ & None & None & Strong green & None \\
\hline \multicolumn{5}{|l|}{$\begin{array}{l}\text { Fluorescence to } \\
\text { U.V. radiation }\end{array}$} \\
\hline Long-wave & $\begin{array}{l}\text { Very strong } \\
\text { chalky blue }\end{array}$ & None & $\begin{array}{l}\text { Very strong } \\
\text { chalky yellow }\end{array}$ & $\begin{array}{l}\text { Very weak } \\
\text { yellowish orange }\end{array}$ \\
\hline Short-wave & $\begin{array}{l}\text { Moderate chalky } \\
\text { blue }\end{array}$ & None & $\begin{array}{l}\text { Moderate chalky } \\
\text { yellow }\end{array}$ & None \\
\hline Phosphorescence & $\begin{array}{l}\text { Very weak dull } \\
\text { chalky yellow, } \\
\text { long-wave U.V. }\end{array}$ & None & None & None \\
\hline $\begin{array}{l}\text { Electrical } \\
\text { conductivity }\end{array}$ & Nonconductive & Conductive & Nonconductive & Nonconductive \\
\hline
\end{tabular}


for personal use is perfectly legal in Indonesia, but there are special requirements for obtaining a business visa. The jewelry is both made locally and also imported as halfmounts from Hong Kong and Bangkok. The round brilliant is virtually the exclusive cut in Martapura. A marquise-cut diamond shown to one of the coauthors was described as a "very unusual fancy cut." The faceting machines used are typical of those found in India, with heavy bronze wheels attached by a spindle with bearings on the top and bottom. One electric motor will run from one to six cutting wheels by means of a belt.

The grading of diamonds in Kalimantan is reminiscent of the grading in existence around the turn of the century. Color is graded as blue-white (biru), white (putih), yellowish (kuning), brownish (coklat), and, of course, the fancy colors. Clarity is divided into "loupe clean," "slightly imperfect," etc. No microscopes or modern diamond-grading equipment (or terminology) were in evidence during Dikinis's 1987 visit. Some fine cut stones in 3to 5-ct sizes, as well as one 10-ct, were available at that time. The prices for rough were based on what kind of a finished round stone the rough should produce. The largest consumers of the finished cut stones are the jewelry stores in Jakarta, so the prices are fairly consistent with the international market.

\section{RECENT PRODUCTION AND FUTURE POTENTIAL}

Schubnel $(1980)$ estimated that annual diamond production from southeastern Kalimantan ranged between 20,000 and 30,000 ct. In 1984, however, Diamond World Review gave production estimates for Borneo of 15,000 ct per year. During Dikinis's visit in the summer of 1987, only about five rough stones (over $0.50 \mathrm{ct}$ ) a day came on the open market in Martapura (although a somewhat greater number were undoubtedly sent directly to the local cutting facilities). During a subsequent visit to the mining town of Cempalka, Dikinis also observed that a full day of prospecting produced only three gem-quality stones. These figures are low enough that the government and the international community pay little attention to the native workings of southeastern Kalimantan.

The best hope for increasing diamond production in Kalimantan is through large-scale, mechanized mining. Several corporations are actively exploring for both alluvial diamonds and possible kimberlite pipes in the Meratus Mountains and elsewhere. The most advanced of these diamond projects in Kalimantan is that of the Aneka Tambang-Acorn Securities-Keymead joint venture in the Cempaka district.

At the time of printing, Acorn has completed an additional large bulk sample as well as several smaller bulk samples using sheet pile caisson techniques driven by crane-mounted vibro-hammers. The Cempaka swamp, as well as Danau Seran, has now been sampled. A detailed feasibility study prepared in conjunction with Alluvial Dredges Ltd. of Scotland proposes a $16-\mathrm{ft}^{3}$ bucketladder dredge for the Danau Seran paleochannel that would remove the overburden and some $800,000 \mathrm{~m}^{3}$ of diamondiferous gravel per annum for five years to produce approximately $100,000 \mathrm{ct}$ per annum of gem-quality diamonds. The proposal also calls for an additional two $36-\mathrm{ft}^{3}$ bucket-line dredges to mine the deeper Cempaka paleochannel at an annual production of 200,000 ct.

The high unit value of the diamonds enables the relatively low in-situ grades to be profitably mined using these sophisticated high-volume extraction techniques. With the success of this project, it is hoped that Indonesia will become a small but consistent producer of high-quality gem diamonds.

\section{REFERENCES}

Ball S.H. (1931) Diamond mining in Borneo. Engineering and Mining Journal, Vol. 132, No. 5, pp. 200-204.

Bauer M. (1904) Precious Stones. Trans. by L. J. Spencer, Charles Griffin \& Co., London.

Boutan E. (1886) Diamant. C. Dunod, Paris.

Bruton E. (1978) Diamonds, 2nd ed. Chilton Book Co., Radnor, PA.

Diamond World Review (1984) Vol. 8, No. 33, p. 2116.

Hamilton W. (1970) Tectonics of the Indonesian Region. Report published by the Indonesian Geological Survey.

The petrified tears of Queen Ratu Inan (1977) Indiaqua, Vol. 1, No. 15, pp. $15-19$.

Nixon P.H., Bergman S.C. (1987) Anomalous occurrences of diamonds. Indiaqua, No. 47, pp. 21-27.

Schubnel H-J. (1980) Other producers. In \}. Legrand, Ed. Diamonds: Myth, Magic, and Reality, Crown Publishers, New York, pp. 180-187.

Tavernier J-B. (1676) Travels in India. Trans. by V. Ball, Oriental Reprint Corp., New Delhi, India.

Van Bemmelen, R. W. (1939) De geologie van het westelijke deel van de Westerafdeeling van Borneo (geology of the western part of southwest Borneol. N. E. I. Dienst v. d. Minbouw, Jaarb., Vol. 68, pp. 187-328.

Webster R. (1983) Gems: Their Sources, Descriptions, and Identification, 4th ed. Butterworths, London, England. 